\title{
ТРУДОВОЕ ВОСПИТАНИЕ КАК ОДНО ИЗ СРЕДСТВ ФОРМИРОВАНИЯ СОЦИАЛЬНЫХ КОМПЕТЕНЦИЙ ОБУЧАЮЩИХСЯ
}

\section{Салимгареева Гузелия Фаритовна Валитова Маргарита Поликарповна Биктимирова Эмма Дамировна} ГБОУ Нефтекамская коррекционная школа-интернат для детей с ограниченными возможностями здоровья

\begin{abstract}
Аннотации: главной целью учителя является помощь детям с ограниченными возможностями здоровья. Им нужно помочь социально адаптироваться, самореализоваться в обществе. Если здоровый ребенок познает окружающий мир не только на уроке, но и в большей степени, во внеурочное время, когда ребята получают возможность непосредственного общения со сверстниками, то дети с ограниченными возможностями здоровья лишены такой возможности. Грамотная организация профессионально трудовой деятельности для таких детей может ступенькой для последующей социализации и адаптации детей в современном обществе, открыть возможности для самореализации и профессионального определения.
\end{abstract}

Ключевые слова: трудовое воспитание, социальная адаптация, самореализация, профессиональное определение.

\section{Трудовое воспитание - одно из средств формирования социальных компетенций обучающихся}

Современный этап общественного развития характеризуется стремительно разворачивающимися инновационными преобразованиями различных сфер жизнедеятельности человека, в том числе и социальной. Обществу и государству сегодня нужны люди, умеющие социализироваться в быстроизменяющемся социуме, люди творческие, активные, владеющие универсальными способами действий. Ответом системы образования на этот запрос времени стала идея компетентного подхода в обучении, реализованная в Федеральных государственных образовательных стандартах второго поколения. Отличительной особенностью новых Стандартов является усиление практической жизненной направленности образования. В структуре ключевых компетентностей значительное место уделено социальной 
компетентности как готовности и способности к социальному взаимодействию в разных жизненных сферах, как единству социальной адаптации и мобильности. Проводимая в стране модернизация образования ориентирует школу на поиск путей и способов развития адаптационных способностей личности и обеспечение ее социальной компетентности.

Основным направлением работы нашей школы является социальная адаптация детей с умственной отсталостью (интеллектуальными нарушениями). Эти воспитанники не в состоянии сами выделить, освоить и усвоить те звенья социальных структур, которые позволяют личности комфортно поддерживать существование в социальной среде и успешно реализовывать в ней свои потребности и цели. По сути, они лишены основы самостоятельного, благополучного существования в сложном современном социуме. Поэтому социальная адаптация является не только важнейшей задачей обучения и воспитания детей с умственной отсталостью (интеллектуальными нарушениями), но и средством компенсации первичного дефекта. Возможность овладения профессией обучающимися во многом зависит от проводимой в школе четкой организации профессиональнотрудового обучения (таблица 1), которая позволяет дать такое обучение, воспитание и сопровождение обучающихся, которое позволило бы им адаптироваться к условиям жизни в современном мире, получить доступную для них степень независимости и самостоятельность в труде, быту и в свободное время (рис.1-6).

Таблица 1

Сравнительный анализ качества знаний обучающихся за 3 года

\begin{tabular}{|l|c|c|c|c|}
\hline \multicolumn{1}{|c|}{ Предмет } & \multirow{2}{*}{ класс } & \multicolumn{4}{|c|}{ Качество знаний, \% } \\
\cline { 2 - 5 } & & $2017-2018$ & $2018-2019$ & $2019-2020$ \\
\hline \multirow{2}{*}{$\begin{array}{l}\text { Цекетоводство и } \\
\text { садоводство }\end{array}$} & $6 \mathrm{a}$ & - & 80 & 80 \\
\cline { 2 - 5 } & $7 \mathrm{a}$ & 50 & 100 & 100 \\
\cline { 2 - 5 } Парикмахерское дело & 9 & 67 & 100 & 100 \\
\cline { 2 - 5 } & $5 \mathrm{a}$ & - & - & 80 \\
\cline { 2 - 5 } & $6 \sigma$ & - & 75 & 75 \\
\hline \multirow{3}{*}{ Швейное дело } & $7 \mathrm{a}$ & 83 & 83 & 100 \\
\cline { 2 - 5 } & 76 & - & 75 & 75 \\
\hline
\end{tabular}




\begin{tabular}{|l|c|c|c|c|}
\hline Обувное дело & $8 \mathrm{a}$ & 83.3 & 66.6 & 100 \\
\hline \multirow{5}{*}{ Столярное дело } & $5 \mathrm{a}$ & - & - & 100 \\
\cline { 2 - 5 } & $6 \mathrm{a}$ & - & 89 & 93 \\
\cline { 2 - 5 } & 76 & 95 & 96 & 92 \\
\hline \multirow{2}{*}{\begin{tabular}{l} 
малукатурно- \\
\cline { 2 - 5 }
\end{tabular}} & $8 \mathrm{a}$ & 83 & 100 & 80 \\
\cline { 2 - 5 } & 86 & 100 & 100 & 100 \\
\hline
\end{tabular}

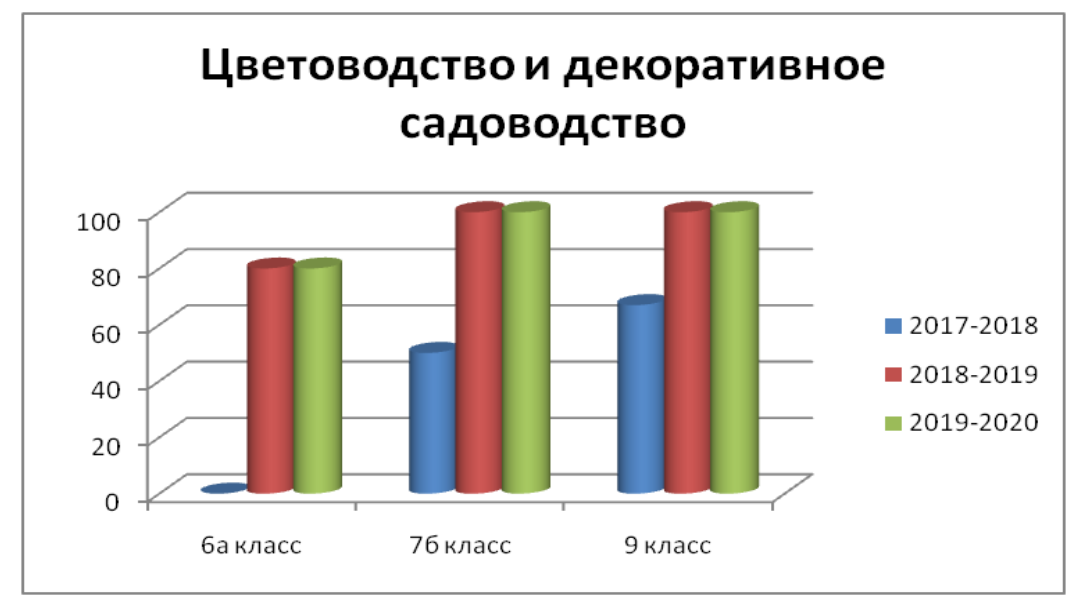

Рис. 1. Цветоводство и декоративное садоводство

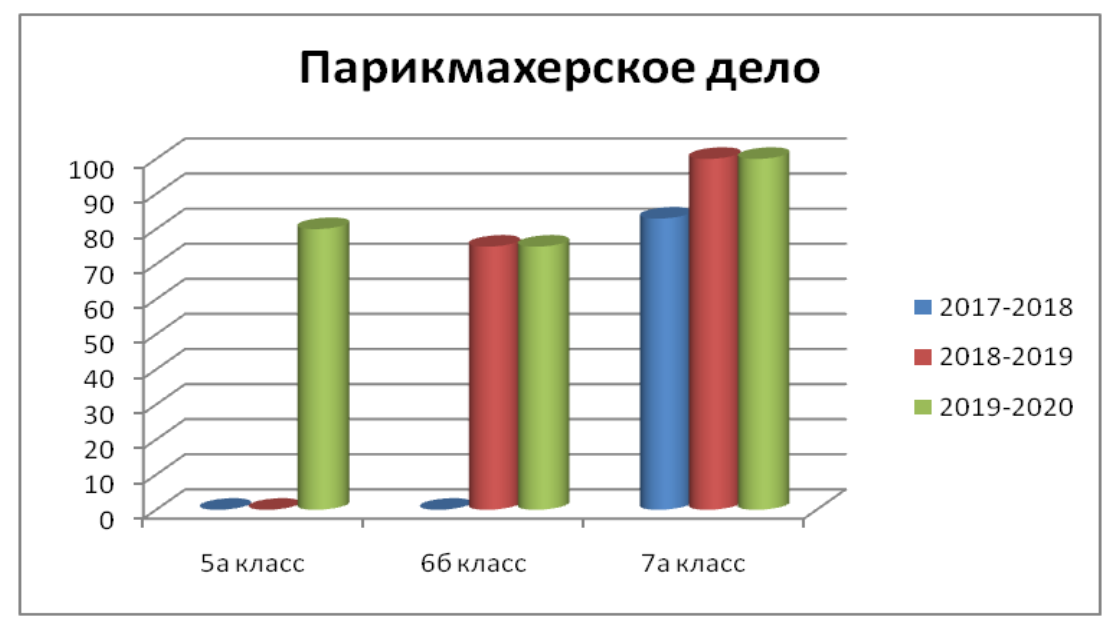

Рис. 2. Парикмахерское дело 


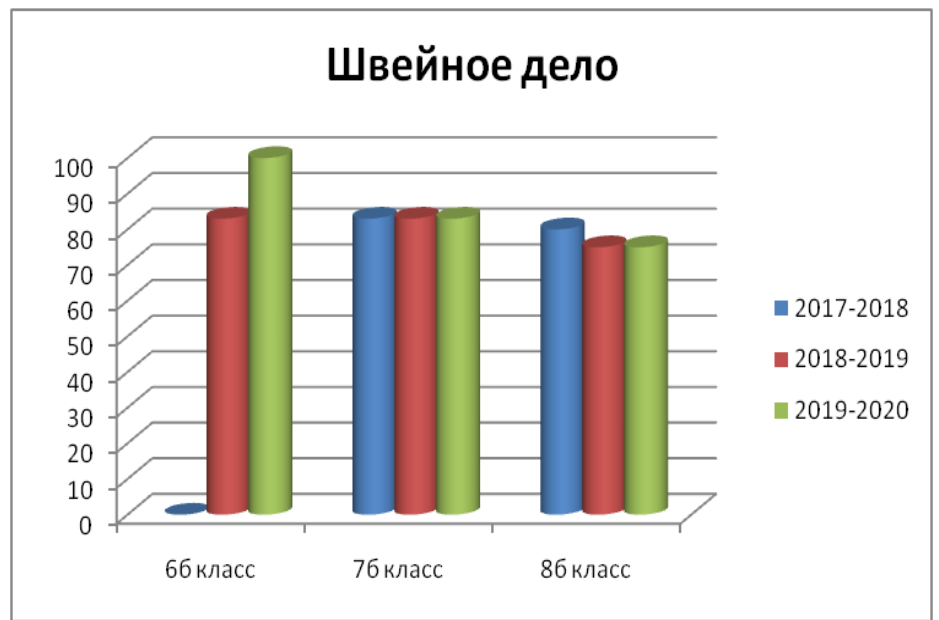

Рис. 3. Швейное дело

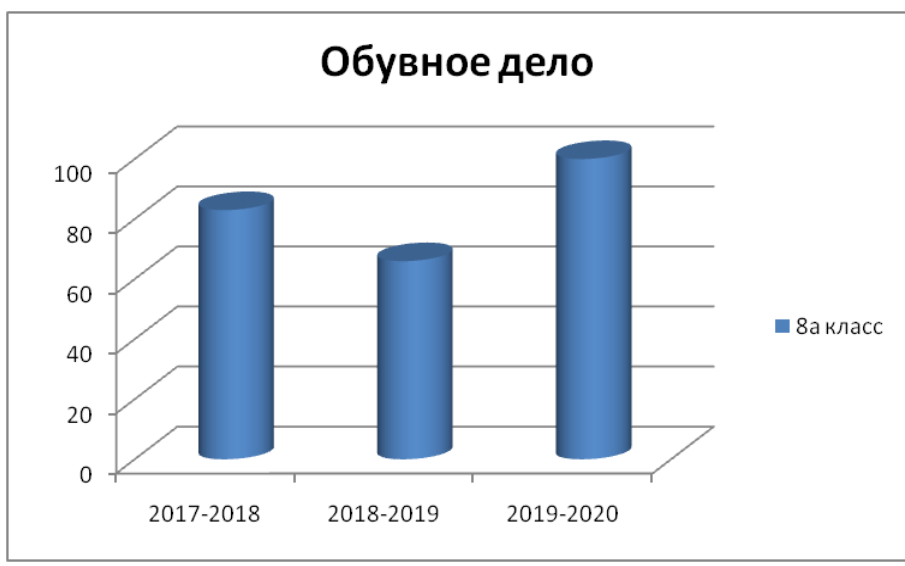

Рис.4. Обувное дело

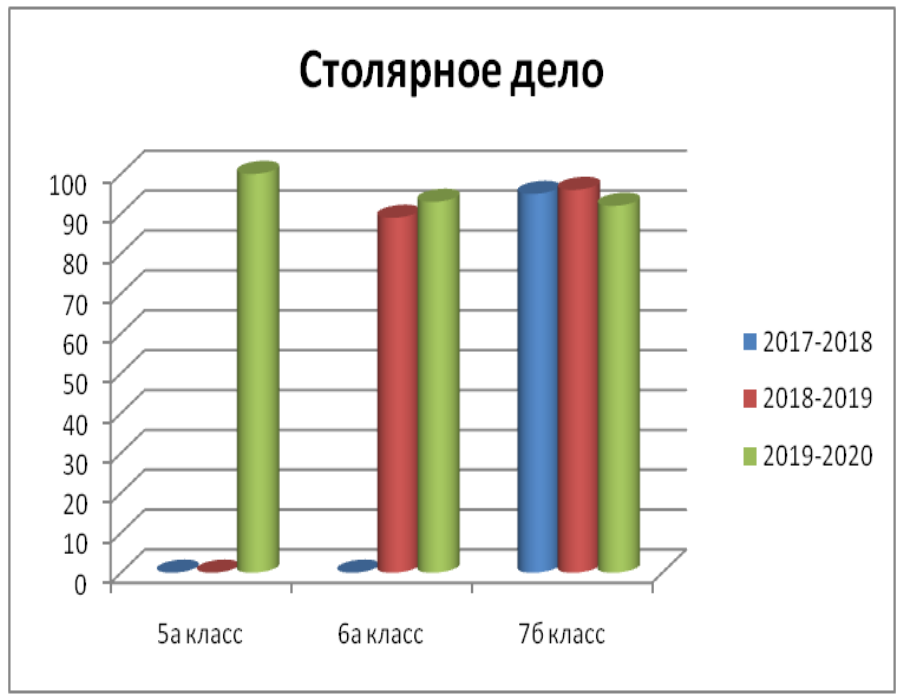

Рис.5. Столярное дело 


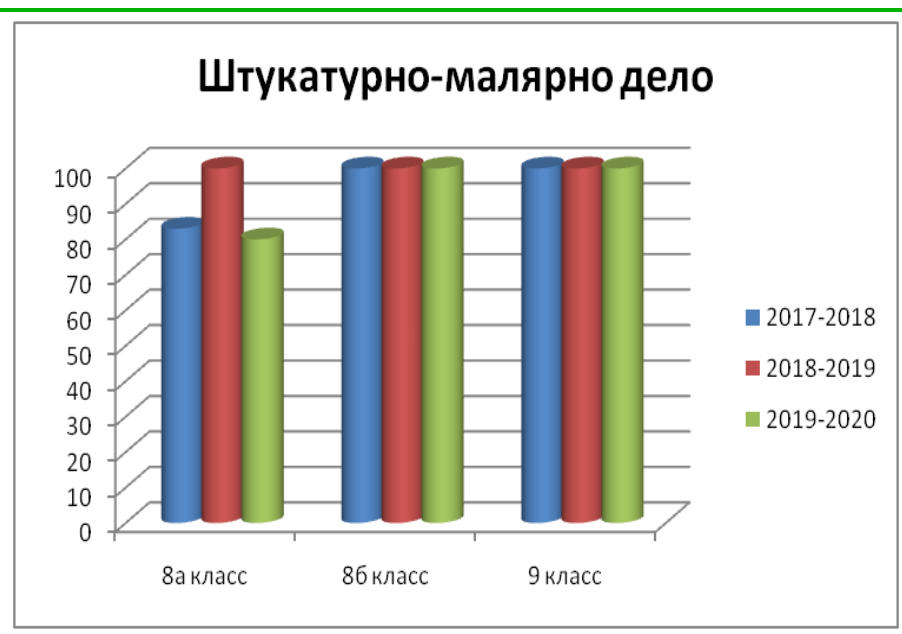

\section{Рис.6. Штукатурно - малярное дело}

Детям трудно адаптироваться к самостоятельной жизни за стенами школы-интерната. Поэтому, на наш взгляд, главной задачей социальнопедагогической работы является подготовить воспитанников школы к самостоятельной жизни, повысить уровень их социальной компетентностизначит повысить их социальную защищенность. Одним из средств формирования социальных компетенций обучающихся является профессионально-трудовое воспитание.

В широком смысле профессионально-трудовое обучение и воспитание включает две группы задач:

а) формирование у обучающихся прочных трудовых умений, навыков, воспитания культуры труда и умений использовать в практической деятельности общеобразовательные знания и навыки;

б) воспитание у обучающихся таких нравственных качеств, как трудолюбие, ответственное отношение к заданиям, бережное отношение к общественному имуществу, умение работать в коллективе и выполнять требования трудовой дисциплины. Кроме того, профессионально-трудовое воспитание в школе выполняет функции социально-трудовой реабилитации и адаптации обучающихся.

Первые навыки любви к труду ученики приобретают в начальной школе на уроках ручного труда, рисования, изобразительной деятельности, во внеурочной деятельности, а также в процессе самообслуживания. Всевозможные поделки и другие творческие работы, создаваемые ребятами на данных уроках, не только развивают их творческие способности, учат 
правильно организовывать сам процесс труда и творчества, но и имеют огромное воспитательное значение. Вся система уроков предметной области
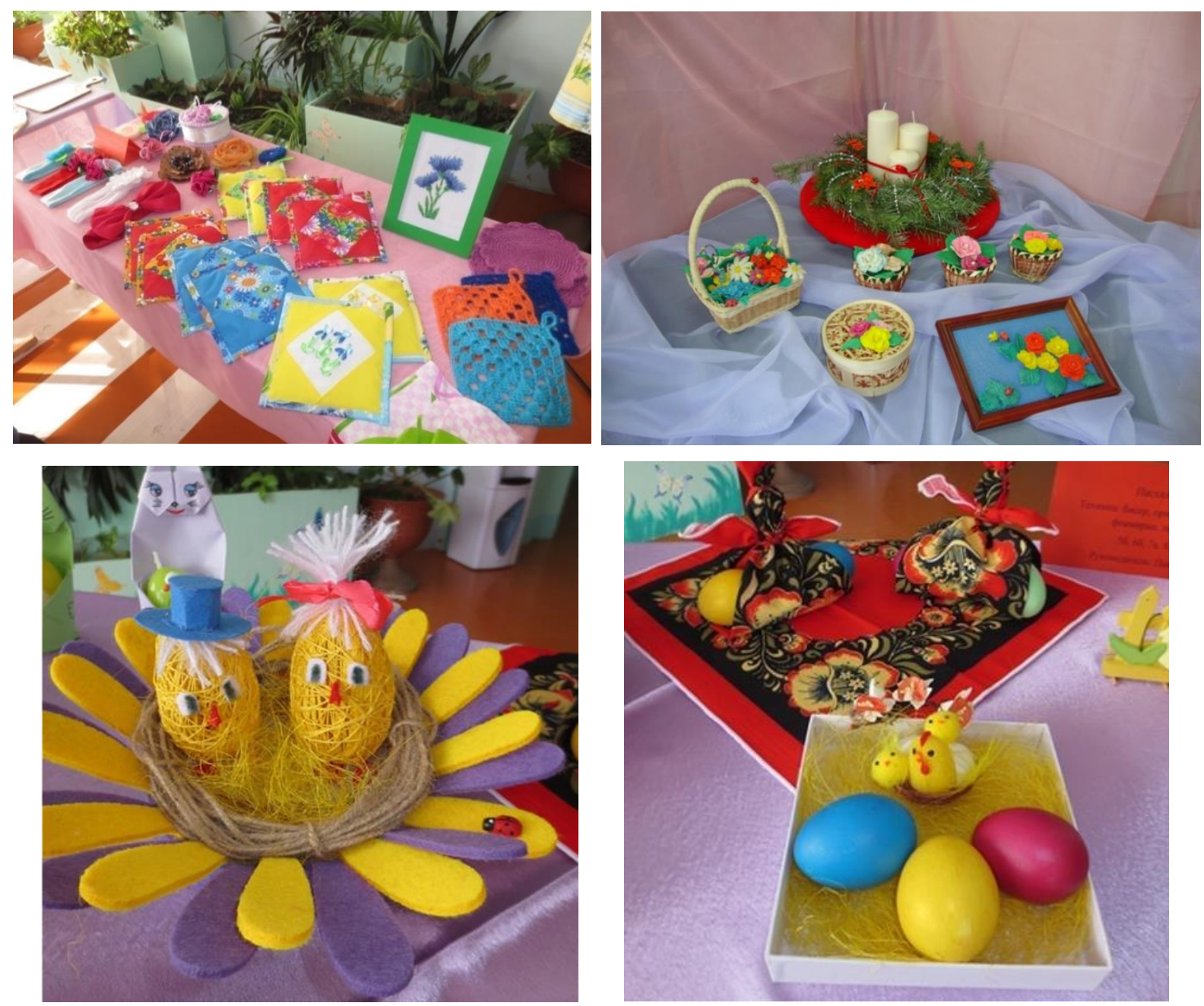

Рис. 7. Участие обучающихся 1-4 классов в общешкольных мероприятиях

«Технология» в начальной школе адаптирована к системе общешкольных мероприятий. Так, младшие школьники готовят поделки ко Дню Матери, Дню Учителя, Новому году, Дню защитника Отечества, Международному дню 8 Марта, Дню Победы, различным тематическим выставкам (рис. 7).

В формировании социальной компетенции у обучающихся 5-9 классов играет немаловажную роль правильная организация трудового процесса на уроках профессионально-трудового обучения, основы социальной жизни и социально-бытовой ориентировки. 
Профессионально-трудовое обучение имеет общетехнический характер, является пропедевтическим периодом для формирования ключевых компетенций, необходимых для дальнейшей профессиональной деятельности. В данный период определяются индивидуальные профессиональные возможности обучающихся в овладении тем или иным видом профессионального труда. В нашей школе обучающиеся осваивают следующие профили профессионально-трудового обучения: штукатурномалярное, швейное, столярное, обувное, парикмахерское дело, цветоводство и декоративное садоводство (рис. 8).

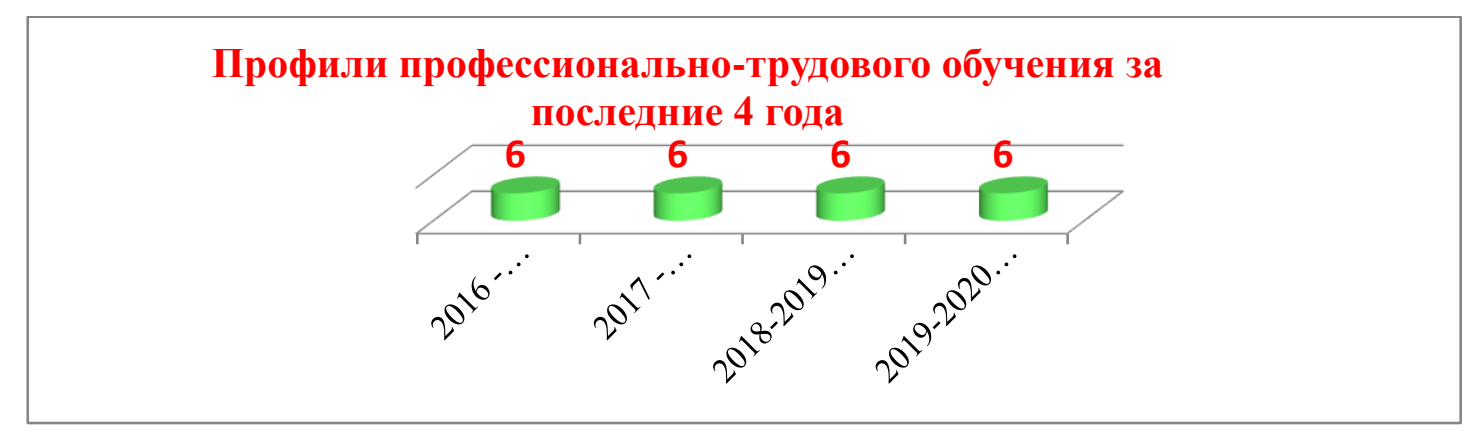

\section{Рис. 8. Профили профессионально-трудового обучения} за последние 4 года

При практической работе обучающиеся объединяются в группы и распределяются обязанности по организации трудового процесса.

Воспитательный эффект особенно велик тогда, когда сами обучающиеся принимают участие в организации трудового процесса (рис.9) и в оценке полученных результатов. За выполненную работу несут ответственность все члены команды, и если один из команды допустил ошибку при выполнении определенной операции, то общая работа показывает низкие результаты. За время работы в команде обучающиеся с ограниченными возможностями здоровья используют и совершенствуют знания, умения и навыки, полученные на уроках и как, показывают наблюдения, такая организация урока оказывает положительное воспитательное влияние на формирование социальных навыков обучающихся. 

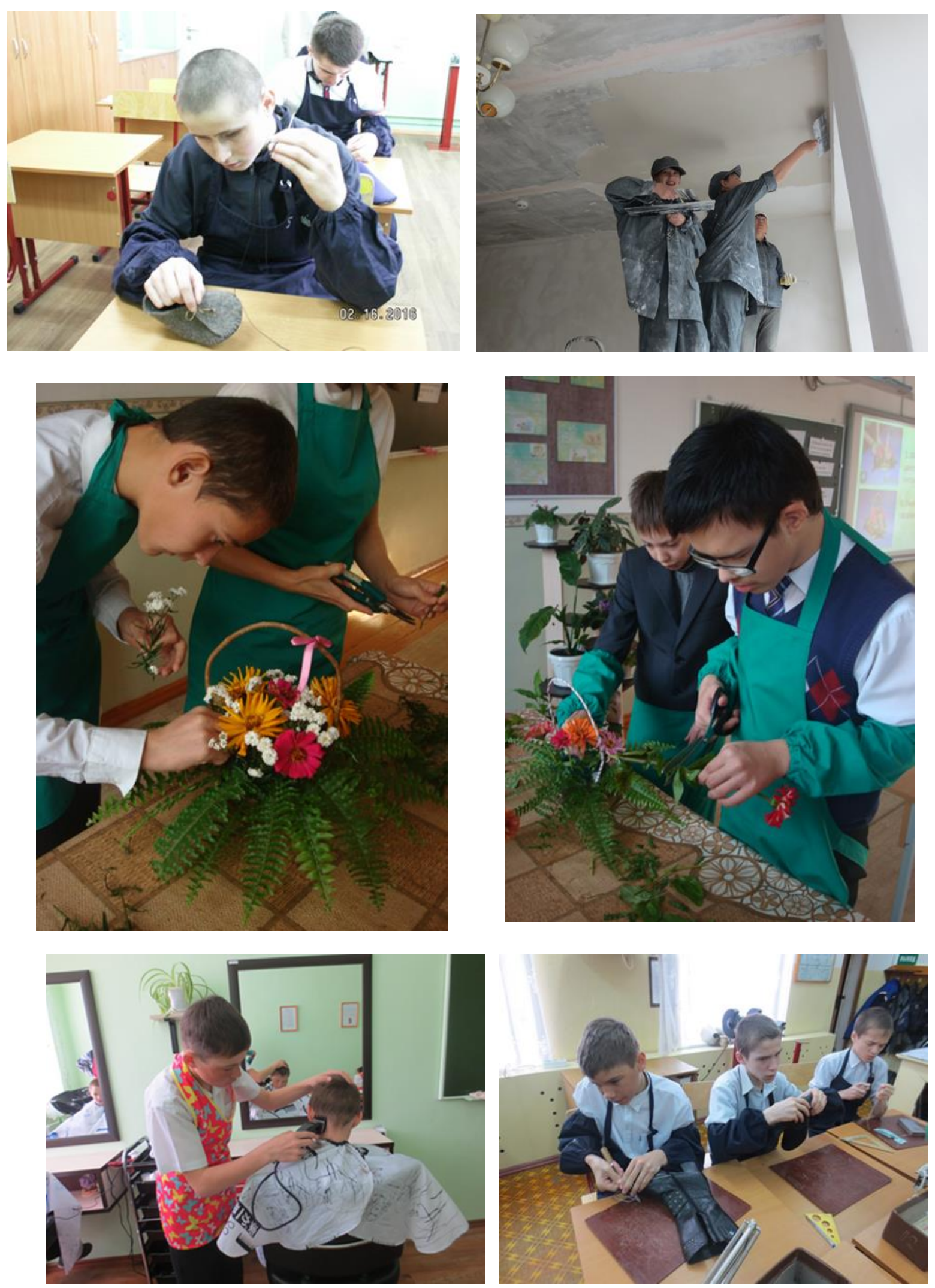

Рис. 9. Участие обучающихся 5-9 классов

в организации трудового процесса 
Это находит свое выражение в том, что обучающиеся со временем более критично относятся к своим результатам, проявляют большую активность и заинтересованность в достижении лучших показателей по профессиональнотрудовому обучению и воспитанию (таблица 2).

Таблица 2

Диагностика учебных достижений по результатам итоговой аттестации по трудовому обучению

\begin{tabular}{|l|c|c|}
\hline \multicolumn{1}{|c|}{$\begin{array}{c}\text { Название учебного } \\
\text { предмета }\end{array}$} & $\begin{array}{c}\text { Счебный год } \\
\text { балл }\end{array}$ \\
\hline Швейное дело & $2015-2016$ & 4.2 \\
& $2016-2017$ & 4.3 \\
\hline Штукатурно-малярное & $2017-2018$ & 4 \\
\hline дело & $2014-2015$ & 3.8 \\
& $2015-2016$ & 3.8 \\
\hline Цветоводство & $2019-2020$ & 4.6 \\
\hline декоративное садоводство & $2017-2018$ & 3.6 \\
& $2018-2019$ & 4.3 \\
\hline Обувное дело & $2019-2020$ & 4.7 \\
\hline Парикмахерское дело & $2015-2016$ & 4.6 \\
& $2016-2017$ & 4.2 \\
\hline Столярное дело & $2017-2018$ & 5 \\
\hline
\end{tabular}

Радует то, что практически все обучающиеся работают с большим интересом, плодотворно. К выполнению своей работы подходят со всей ответственностью. Это дает воспитанникам возможность наглядно убедиться в результатах своего труда, что является лучшей мотивацией к дальнейшему освоению профессии (рис.10-11). 


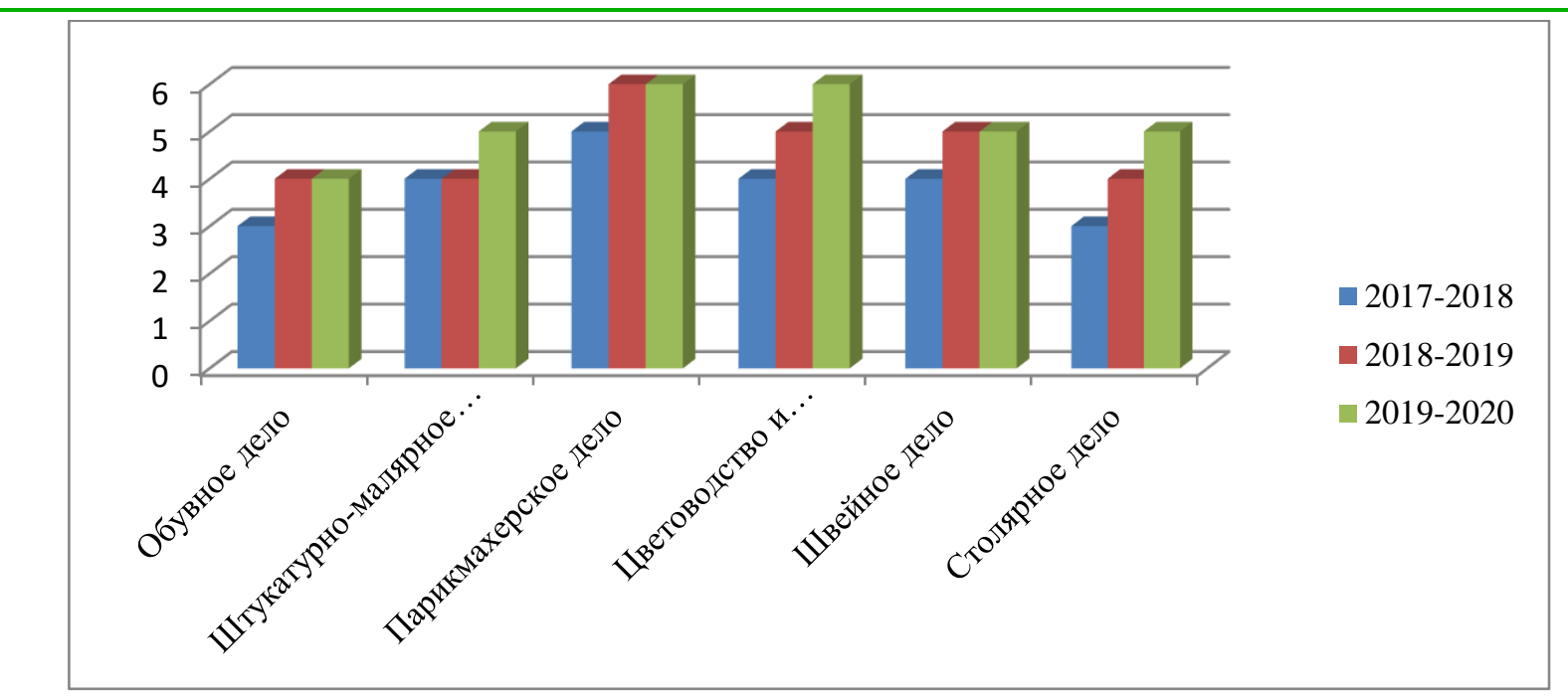

Рис. 10. Результаты конкурса «Лучший по профессии» за последние 3 года

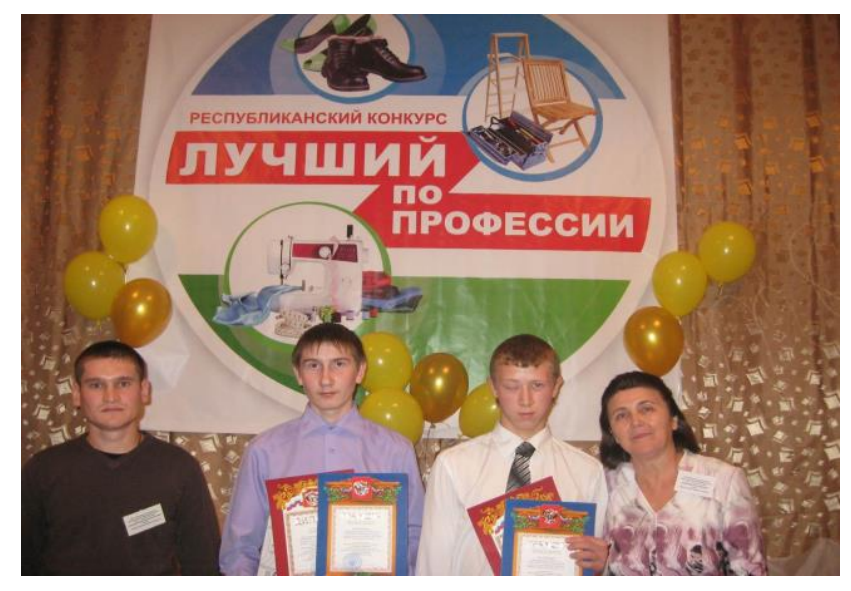

\section{Рис.11. Участие в республиканском конкурсе «Лучший по профессии»}

Знания, полученные школьниками на уроках труда, повышают общий уровень интеллекта и создают основу для развития умений правильно регулировать свою деятельность при решении трудовых задач. У подавляющего большинства обучающихся школы формируются высокоавтоматизированные навыки выполнения несложных трудовых операций.

Имеет большое значение в формировании социальной компетенции обучающихся с ограниченными возможностями здоровья ежегодные праздники труда в школе. Участие в выставках декоративно-прикладного творчества дает возможность ученикам показать себя, посмотреть и пообщаться с другими сверстниками. 
Участие в ежегодных ярмарках изделий, изготовленных своими руками, учат их реализовать товар с учетом рыночных отношений.

Таблица 3

Участие обучающихся в различных конкурсах

\begin{tabular}{|c|c|c|}
\hline № & Конкурс & Результат \\
\hline 1. & $\begin{array}{l}\text { Всероссийский конкурс «Декоративно- } \\
\text { прикладного творчества», «Трям! Здравствуйте!» } \\
\text { (коллективная работа), ноябрь, 2019г. }\end{array}$ & Диплом 1 место \\
\hline 2. & $\begin{array}{l}\text { Международный конкурс «Декоративно- } \\
\text { прикладного творчества: Вышивка», «Подушка } \\
\text { для мамы», декабрь, 2019г. }\end{array}$ & Диплом 1 место \\
\hline 3. & $\begin{array}{l}\text { Всероссийский конкурс «Творчество без границ», } \\
\text { «Волшебные мгновения лета», декабрь 2019г. }\end{array}$ & Диплом 1 место \\
\hline 4. & $\begin{array}{l}\text { Всероссийская предметная олимпиада по } \\
\text { швейному делу, декабрь 2019г. }\end{array}$ & Диплом 2 место \\
\hline 5. & $\begin{array}{l}\text { Всероссийская предметная олимпиада по } \\
\text { предмету «Рукоделие. Вязание крючком», } \\
\text { «Рукоделие. Вязание крючком», декабрь 2019г. }\end{array}$ & Диплом участника \\
\hline 6. & $\begin{array}{l}\text { Всероссийский конкурс детского творчества РОС } \\
\text { Обрконкурс, «Новый год приходит», декабрь } \\
\text { 2019г. }\end{array}$ & Диплом участника \\
\hline 7. & $\begin{array}{l}\text { Всероссийский конкурс детского творчества РОС } \\
\text { Обрконкурс, «Символ года», декабрь 2019г. }\end{array}$ & Диплом участника \\
\hline 8. & $\begin{array}{l}\text { Всероссийский конкурс Методическая разработка } \\
\text { «Инструменты и орудия труда для ухода за } \\
\text { кустарниками», 02.12.2019г. }\end{array}$ & Участник \\
\hline 9. & $\begin{array}{l}\text { I этап (региональный) IV Всероссийского } \\
\text { конкурса «Школа - территория здоровья» } \\
\text { «Лучший конспект урока с применением } \\
\text { здоровьесберегающих технологий» }\end{array}$ & Участник \\
\hline 10. & $\begin{array}{l}\text { Городской конкурс детского творчества «Талант с } \\
\text { колыбели», посвященном Международному } \\
\text { женскому дню } 8 \text { Марта, } \\
\text { «Шкатулка для вязания», «Весеннее настроение» }\end{array}$ & Диплом участника \\
\hline 11. & $\begin{array}{l}\text { Коллективная работа «Башкортостан - чудесный } \\
\text { край», XIV Республиканский культурно- } \\
\text { спортивный фестиваль, октябрь }\end{array}$ & участие \\
\hline
\end{tabular}


Еще больше значения придается общественно-полезному труду. Следует отметить, что для повышения интереса и активности школьников в процессе обучения необходимо, чтобы они осознавали важность и полезность того, что они делают, понимали, что результаты их деятельности имеют известное практическое и общественное значение. Такому осознанию содействует соединение обучения с общественно полезным трудом. В процессе физического труда создаются условия для проявления детьми нравственных качеств: коллективизма, взаимопомощи, уважения к людям и результатам их трудовой деятельности. Общественно полезный труд включает: труд по самообслуживанию в школе и дома (уборка класса, школьной территории, бытовой труд дома, уход за зелеными насаждениям и др.).

Производительный труд предполагает участие школьников в создании материальных ценностей, вступление в производственные отношения. Участие в производительном труде развивает у обучающихся профессиональные интересы, склонности, потребности в труде, они познают смысл экономики и хозяйствования. Формы производительного труда: производственные бригады школьников по ремонту и озеленению территории.

Вся учебно-воспитательная работа в школе направлена на то, чтобы каждый обучающийся ясно представлял своё место в трудовом процессе, знал, что и зачем он делает, чувствовал, что его работа - необходимая часть общего труда. Задача педагогического коллектива состоит в том, чтобы создать условия для работы по профессионально-трудовой подготовке с целью успешной адаптации и социализации выпускников школы в современном обществе, формирования умений быть востребованными на рынке труда, развивать творческие связи с образовательными организациями профессионального и дополнительного образования, с общественными организациями для создания условий, способствующих успешной самореализации и социализации, как педагогов, так и выявлению и развитию обучающихся.

Таким образом, наши ребята могут самостоятельно выстроить свой жизненный путь и успешно реализовать себя в быстро меняющихся экономических условиях. 


\section{Список литературы}

1. Царев А.М. Организация обучения и воспитания детей подростков с тяжелыми и множественными нарушениями развития в Псковском Центре лечебной педагогики // Воспитание и обучение детей с нарушениями развития.- 2011.- №4.- С.12-23.

2. Саркисян Л.И. Социализация и интеграция в общество детей с особенностями психофизического развития. // Воспитание и обучение детей с нарушениями развития.-2015. - №1 .- С.20-23.

( Г.Ф. Салимгареева, М.П. Валитова, Э.Д. Биктимирова, 2020 